DEPARTMENT OF THE INTERIOR

UNITED STATES GEOLOGICAL SURVEY

MAPS SHOWING AEROMAGNETIC ANOMALIES, FAULTS,

EARTHQUAKE EPICENTERS, AND IGNEOUS ROCKS IN THE

SOUTHERN SAN FRANCISCO BAY REGION, CALIFORNIA

By Earl E. Brabb and William F. Hanna 


\title{
MAPS SHOWING AEROMAGNETIC ANOMALIES, FAULTS, EARTHQUAKE EPICENTERS, AND IGNEOUS ROCISS IN THE SOUTHERN SAN FRANCISCO BAY REGION, CALIFORNIA
}

\author{
By Earl E. Brabb and William F. Hanna
}

\section{INTRODUCTION}

The identification of active faults is crucial to developing means for reducing earthquake hazards (see, for example, Wallace, 1974). Some active faults are discernible by traditional methods based on observations of the ground surface; others escape detection because they are covered by overburden or are exposed only in highly inaccessible areas. Traditional methods for identifying active faults include studies of geomorphic forms, such as offset streams, shutter ridges, sag ponds, and linear valleys; field mapping to find places where lithologic or structural units are truncated or displaced; geodetic observations to determine differential movement of large areas of land; measurement of strain; monitoring of small earthquakes; and direct observation of features displaced during major earthquakes. Methods needed to detect faults not identifiable by traditional means are based largely on geophysical and geochemical approaches.

Of special interest in the present study is the use of aeromagnetic anomalies to identify fault systems, notably those systems that contain anomalously magnetic material within the fault zone or those that displace highly magnetic rock terranes in the earth's upper crust. This study was prompted by the observation that the Hayward fault-one of the major earthquake-generating faults in the San Francisco Bay region (Wesson and others, 1975, table 1) -is associated with a prominent magnetic anomaly. The fault also coincides with a line of earthquake epicenters, shown on the map of Brown and Lee (1971). We decided to investigate these correlations in a larger area in order to evaluate the usefulness of magnetic anomaly and earthquake epicenter maps in looking for active faults.

\section{Acknowledgments}

We wish to express our appreciation to J. R. LeCompte, who assisted in the compilation and drafting of the maps of faults and igneous rocks; W. H. K. Lee, who facilitated the preparation of the map of earthquake epicenters; and D. G. Herd, who provided data for the fault map.

\section{General Methodology}

An aeromagnetic survey (index map, area 1, sheet 1) was planned by the authors in 1972 to include all of the known or suspected active faults in the San Francisco Bay region over which data had not previously been obtained. The aeromagnetic survey was conducted in 1973 and was released to the public the following year (U.S. Geol. Survey, 1974). The anomaly map was combined with three older maps (index map, areas 2, 3, and 4, sheet 1), and with one recent map (index map, area 5, sheet 1) in an attempt to complete, as economically as possible, coverage of sheet 3 of the U.S. Geological Survey's 1:125,000 topographic map of the San Francisco Bay region.

As an aid in interpreting the sources of the magnetic anomalies, a special geologic map (sheet 1) was compiled showing all known and suspected exposures of magnetic rocks. Next, the trends of elongate magnetic anomalies were plotted through the areas of greatest magnetic intensity, in much the same way that axes of anticlines are shown on a geologic map. Areas with distinctively different magnetic character were differentiated (sheet 2). After the trend lines were plotted, information on mapped faults (sheet 3) and earthquake epicenters (sheet 2) was superimposed. Upon inspection of the overlapping magnetic anomaly, fault, and epicenter data, one change was made in the anomaly trend map (sheet 3 ). Trend lines corresponding to the Doolan-Tesla anomalies, which originally extended across the Greenville fault, are now shown as interrupted at this fault. Closer inspection of these anomalies showed subtle differences in character on opposite sides of the fault which suggest that two completely different bodies of magnetic rocks have been fortuitously juxtaposed.

The final compilation of inferred faults was based on a combination of geologic, magnetic, fault, and epicenter data.

Magnetic Anomaly Interpretation

Type of analysis. Interpretation of magnetic anomaly data was restricted to a qualitative analysis because of the objectives of the study and the nature of the data set. The composite anomaly map (sheet 1) consists of five data sets, each having distinctive flight specifications and data reduction histories. Despite the contrasting characteristics of adjoining surveys, it was possible to define a number of coherent magnetic anomalies that extend throughout parts of the study area. Those anomalies that appear to be of greatest use in defining fault systems are linear or elongate features, which reflect magnetic material narrowly confined to the zones rather than gradient features, which reflect the truncation of terranes of magnetic rock.

Assumptions. In the present study, faults inferred from magnetic anomaly data are defined in a broad sense to mean zones of crustal weakness. Sources of elongate anomalies are inferred to be steeply dipping tabular bodies generally in the form of pliable ribbons, which in places are confined to vertical strike-slip fault zones and in other places form steeply dipping segments of folded sheets. Most of the tabular sources are inferred to consist of serpentinite because this magnetic material is commonly exposed beneath parts of anomalies in the study area and because serpentinite bodies characteristically generate linear anomalies in neighboring areas of the Califomia Coast Ranges (Griscom, 1966; Hanna and others, 1972). The occurrence of serpentinite, whether lodged within a fault zone or forming part of a folded sheet, generally signals a zone of crustal weakness, both on the basis of the 
stressed environment permitting its emplacement and on the basis that the serpentinite itself is relatively incompetent mechanically.

Blake, Zietz, and Daniels (1977), however, believe that the serpentinite and associated ultramafic rocks were a subhorizontal unit of middle Mesozoic age that has subsequently been folded and faulted during several periods of younger deformation. They would interpret the linear magnetic anomalies not as serpentinite intruded into a fault zone, but as ophiolite fortuitously located near or offset by such young fault systems.

The term magnetization, as used in this report, refers to total magnetization, the combined remanent and induced components. With regard to inferred sources of serpentinite, we assume that the magnetization is parallel to the ambient magnetic field of the earth and, therefore, that either the remanent magnetization is alined with the field or that it is sufficiently random within the material to produce no appreciable external field. This assumption is based in part on reports by Saad (1969a, b), who studied the magnetism of serpentinite and other rocks in the eastcentral part of the map area (sheet 1). It may be noted that in those regions where magnetic anomalies are not associated with rocks believed to be magnetic on the basis of field mapping, either the rocks are (1) unexpectedly nonmagnetic, (2) small in volume, such as very thin sheets, compared to the distance between magnetic rocks and the magnetometer, (3) oriented in such a way, such as horizontally, so that the demagnetizing field of the body causes the anomalous external field in the vicinity of the magnetometer to be small, or (4) a combination of these factors.

\section{Magnetic Anomalies}

Distinctive patterns. Although it will not be possible to make specific inferences about the overall distribution of linear anomalies throughout the study area until an internally consistent data set can be obtained in a future lowlevel survey, the current composite map shows that many such elongate features occur in the region northeast of the San Andreas fault. Southwest of the fault and in an area east of Hollister northeast of the fault, anomalies appear to be less highly linear, that is, either more equidimensional or irregular. Sources of the linear anomalies are inferred to be serpentinite; sources of the other anomalies are inferred to be various volcanic and plutonic rocks. In the following discussion, it is convenient to consider in sequence (1) anomalies southwest of the San Andreas fault, (2) nonlinear anomalies northeast of the San Andreas fault, and (3) linear anomalies northeast of the San Andreas fault. Anomalies southwest of the San Andreas fault: Seven anomalies southwest of the fault are considered sufficiently important for special mention. Of these, the Montara, Half Moon Bay, Mindego Hill, and Logan anomalies have sources that are at least partly exposed. The Año Nuevo, Boulder Creek, and Corralitos anomalies have unknown source rocks buried beneath sedimentary cover.

The negative Montara anomaly is largely associated with quartz diorite of the Montara Mountain area, rocks inferred to possess reversed magnetization. The circular negative anomaly in offshore data southwest of Montara Mountain may mark an offshore continuation of this plutonic rock massif, but the anomaly is on the opposite side of the San Gregorio fault and may not be related. The local northeast-trending Half Moon Bay anomaly is associated with isolated outcrops of Mindego basalt, which is inferred to be normally polarized. The Mindego Hill anomalies to the southeast, which are mainly negative in polarity, are associated with piles of Mindego Basalt inferred to possess predominantly reversed magnetization. There is no strong evidence on the basis of the magnetic data that this basalt extends continuously in the subsurface between the magnetic anomalies.

The Año Nuevo anomaly, a high-amplitude, broadwavelength, positive feature, has a buried source possessing high-intensity normal magnetization. The source rock of this anomaly is separated from that of the Boulder Creek anomaly by the San Gregorio fault, but it has generally similar magnetic character.

The Boulder Creek anomaly is one of the largest magnetic features known in the vicinity of the San Andreas fault system (Hanna and others, 1972). Its source is largely confined in the subsurface between vertical projections of the Zayante and Butano fault traces, and it is terminated in small part by the San Andreas fault. The southeast margin of this anomaly is not precisely defined, although reconnaissance data suggest that its source rock may extend to the region of the Corralitos anomalies. The Corralitos anomalies, like the Boulder Creek feature, have buried source rocks that are normally polarized.

A clue to the nature of source rocks of the Corralitos, Boulder Creek, and Año Nuevo anomalies may be provided by the local high-amplitude Logan anomaly, also at the southwest margin of the San Andreas fault. The Logan anomaly is associated with quartz gabbro and anorthosite gabbro (Ross, 1970) having relative high density (Clark and Rietman, 1973) and strong normal magnetization. Sources of the Boulder Creek and Corralitos anomalies, at least, seem to require magnetizations similar to those of gabbros at the Logan anomaly site. Furthermore, sources of all of these anomalies appear to be confined between the Zayante fault on the southwest and the Butano or San Andreas faults on the northeast. Confirmation of identical sources on the basis of gravity data cannot be established because of occurrences of large accumulations of lowdensity sedimentary cover.

Nonlinear anomalies northeast of the San Andreas fault: A group of local positive anomalies, confined to the southeast comer of the map area, are related mainly to andesite, basalt, and associated igneous intrusive rocks. Maximum values of these anomalies correspond closely to peaks and ridges of ground terrain above $760 \mathrm{~m}$. The magnetic data suggest that these rocks have normal magnetization in contrast to the reversed magnetization inferred to reside in most of the Mindego Basalt on the opposite side of the San Andreas fault.

Other nonlinear anomalies northeast of the San Andreas fault include six oval or equidimensional features in the terrane of serpentinite generally characterized by linear. anomalies. Each of these anomalies has a characteristic which suggests that its source is either a folded or faulted serpentinite sheet, an accumulation of serpentinite at the intersection of two fault zones, or a diapiric intrusion of serpentinite that emerges at the surface through three or more radiating cracks. Three of the nonlinear features, the Point Bonita, San Francisco, and Searsville Lake anomalies, are relatively small (less than $8 \mathrm{~km}$ in diameter) and are within $10 \mathrm{~km}$ of the San Andreas fault. The Calaveras Reservoir, Red Mountain, and Orestimba Creek anomalies are significantly larger and are east of the Hayward or Calaveras faults. Because none of the six anomalies is strongly related to topography, their high amplitudes must be attributable to distinctive shapes of sources rather than to fortuitous proximity of the mag- 
netometer to highly elevated magnetic rocks.

The Point Bonita anomaly, defined by three sets of anomaly data, is characterized by a horseshoe-shaped trend with shallow internal gradients and steep extemal gradients. This feature is interpreted to be caused by a serpentinite sheet fragment in the form of a syncline that plunges southeast. The nearby San Francisco anomaly, marked by four radiating ridgelike trends, may be caused by a complexly folded sheet or by serpentinite injected into intersecting zones of weakness. Some of the complexity could also be due to superimposed cultural effects. The Searsville Lake anomaly appears to be caused by either a northwest-plunging synclinal sheet of serpentinite or by an accumulation of serpentinite at two intersecting segments.

The larger Calaveras Reservoir anomaly is partly associated with serpentinite that has been mapped as a northwest-plunging anticline. Steep gradients on the northeast side of this part of the anomaly indicate that the northeast dip of the serpentinite is steep, within about $15^{\circ}$ of vertical. Farther southeast, the Red Mountain and Orestimba Creek anomalies are broader in wavelength and higher in amplitude than all others shown on the map. Each has a distinctive multiple bifurcation of magnetic trends near their anomaly crests, and each has a serpentinite source of massive proportions. These sources may be fragments of a tabular serpentinite body known to separate the northeast-sloping contact between the Franciscan assemblage and Jurassic and Cretaceous marine sedimentary rocks of the Great Valley sequence in many places of the Coast Ranges of northern California and Oregon. Whether the serpentinite source forms part of a fossil subduction zone or represents material emplaced near the contact of these rock sequences, its restricted extent in appreciable quantities along the strike of the contact remains to be explained. The association of part of the group of Red Hill anomalies with Franciscan volcanic rocks may be accidental. A likely source of this part of the anomaly cluster is serpentinite which may be emplaced beneath these volcanic rocks.

Linear anomalies northeast of the San Andreas fault: Numerous narrow, elongate positive anomalies occur in most of the map area northeast of the San Andreas fault. Most of these features are somewhat isolated and have a strike length of less than $20 \mathrm{~km}$. A few of the features, all having northwest strike directions, extend for as much as $100 \mathrm{~km}$ in well-defined zones. Over half the linear anomalies are associated with mapped serpentinite and few are associated with other rock types believed to be magnetic source rocks. One exception is the Mount Diablo anomaly, which is a narrow southeast extension of a major positive anomaly north of the map area, associated with gabbroic and serpentinite source rocks. Among the various linear anomalies, bifurcating trends occur within the Redwood City, San Jose, Mount Madonna, Gavilan College, Del Valle, and Doolan features. These trends are inferred to be caused by faulting of serpentinite sheets, perhaps accompanied by folding. The group of linear anomalies, as previously noted, is of greatest interest for establishing relations with faulting and seismic activity.

Relation of Linear Anomalies to Faults

Apart from the established correlation of linear anomalies with occurrences of mapped serpentinite, most of these anomalies are also coincident to some extent with mapped bedrock faults. Although uncertainty still exists as to whether the sources of some linear anomalies should be regarded as fragments of folded sheets or as material squeezed into fault segments, the direct association of some linear anomalies with mapped faults is evident. Examples of such correlations with recently active faults include the Hayward anomaly and Hayward fault, the Pulgas Ridge anomaly and Pilarcitos fault, the Mount Madonna anomaly and Sargent fault, and the Gilroy Springs anomaly and the Calaveras fault.

Anomalies within the map area that appear to indicate extensions or connections of fault trace segments which have been previously mapped include the Hunters Point (correlation with thrust fault), Doolan, San Jose, Chesbro, and Gavilan College features. Other linear anomalies may be generally suspected of indicating serpentinite-filled fault zones; the most probable location of the axis of serpentinite emplacement is just northeast of (about $0.25 \mathrm{~cm}$ at scale 1:125,000) and parallel to the magnetic anomaly trend lines. Only those faults containing serpentinite in sufficient quantities for aeromagnetic survey detection will be discovered using this technique. A future low-level aeromagnetic survey of the study area would very likely uncover additional unrecognized faults that contain quantities of serpentinite too small for detection on the current composite anomaly map.

The alternative magnetic anomaly method of identifying faults by truncation of magnetic signatures is of some interest in that a number of linear anomalies in the study area appear to be truncated or separated from nonlinear anomalies by faults. In the heavily serpentinized terrane northeast of the San Andreas fault, two examples of such fault truncation are evident. It appears likely that the Calaveras fault truncates the Chesbro, San Jose, and Alum Rock anomaly sources and possibly the Las Trampas and Danville anomaly sources. The Greenville fault appears to truncate the Red Mountain, Del Valle, and Mount Wallace anomaly sources and possibly the Tesla and Doolan anomaly sources. Inspection of the anomaly map has not revealed any previously unsuspected faults truncating groups of anomalies.

Relation of Linear Anomalies to Seismicity

Because the magnetic anomaly map provides new information about possible locations of faults, it is of interest for purposes of hazards studies to consider the relation of these suspected faults to earthquake activity. A plot of epicenters (sheet 2) covering the period 1969 through 1974 serves as a basis for this comparison. The epicenter plot indicates that a strong positive correlation between linear anomalies and linear distributions of epicenters occurs at the Hayward and Mount Madonna anomaly sites and over the northwest-trending part of the Calaveras Reservoir anomalies; the epicenters and anomalies are along the Hayward, Sargent, and Calaveras faults, respectively. Much weaker positive correlations occur over parts of the San Jose, Los Trancos, San Pedro, Pacifica, Tassajara,San Felipe, and Mount Diablo (presumably having a gabbroic source) anomalies.

If the magnetic and seismic data are compared with locations of mapped faults, other relations become apparent. For example, strong correlation between epicenters and mapped faults occurs at the Calaveras fault and southern part of the San Andreas fault within the map area although magnetic anomalies are absent in these places. Alinements of epicenters between the Hayward and Calaveras faults and between the Del Valle and Tesla anomalies are associated with neither magnetic anomalies nor mapped faults.

Apart from linear distributions of epicenters, the seismic 
data indicate that tightly grouped clusters of epicenters corresponding to earthquake swarms occur in a few regions of the map area. The most conspicuous of these is the Danville cluster (Lee and others, 1971), which has an approximately circular distribution at the northwest extremity of the Doolan anomaly. Although several other epicenter clusters may be identified in various parts of the map area, clusters at the northwest extremity of the Santa Teresa anomaly, northwest extremities of the Calaveras Reservoir anomalies, and southeast break in the Mount Madonna anomaly trend bear approximately the same relation to linear anomalies as the Danville cluster does to the Doolan anomaly. A postulated diapiric intrusive mechanism suggested by Lee, Eaton, and Brabb (1971) for the Danville epicenter distribution may be operative in the other cluster areas. If so, it is possible that the cluster distribution results from sporadic emplacement of serpentinite progressively along a fault zone that is partially filled with serpentinite.

\section{Conclusions}

Of special importance to considerations of geologic hazards, the magnetic, geologic, and seismic data indicate that (1) several elongate magnetic anomalies northeast of the San Andreas fault define steeply dipping ribbons of serpentinite within previously unsuspected fault zones. These fault zones should be studied further to determine whether they are hazardous; (2) none of the previously unsuspected faults is associated with linear patterns of earthquake epicenters; (3) many earthquake epicenters occur in areas where no faults have yet been recognized; (4) the location of a few clusters of epicenters near the extremities of linear magnetic anomalies suggests the possibility that serpentinite is being emplaced diapirically in those areas; (5) the most extensive, previously unrecognized zone of weakness inferred from magnetic data is a lineament defined by the Redwood City and San Jose anomalies, extending from a point about $5 \mathrm{~km}$ east of San Martin for a distance of $85 \mathrm{~km}$ northwest across the San Francisco peninsula to Foster City.

\section{BIBLIOGRAPHY}

Allen, J. E., 1946, Geology of the San Juan Bautista quadrangle, California: California Division of Mines and Geology Bulletin 133, scale 1:62,500.

Bailey, E. H., and Everhart, D. L., 1964, Geology and quicksilver deposits of the New Almaden District, Santa Clara County, California: U.S. Geological Survey Professional Paper 360, 206 p., scale 1:24,000.

Blake, M. C., Jr., Bartow, J. A., Frizzell, V. A., Jr., Schocher, J., Sorg, D., Wentworth, C. M., and Wright, R. H., 1974, Preliminary geologic map of Marin and San Francisco Counties and parts of Alameda, Contra Costa, and Sonoma Counties, California: U.S. Geological Survey Miscellaneous Field Studies Map MF-574, scale $1: 62,500$

Blake, M. C., Jr., Zietz, Isidore, and Daniels, D. L., 1977, Aeromagnetic and generalized geologic map of parts of central California: U.S. Geological Survey Geophysical Investigations Map GP_918.

Brabb, E. E., compiler, 1970, Preliminary geologic map of the central Santa Cruz Mountains, Califomia: U.S. Geological Survey Open-file Report.

Brabb, E. E., Sonneman, H. S., and Switzer, J. R., Jr., 1971, Preliminary geologic map of the Mount DiabloByron area, Contra Costa, Alameda, and San Joaquin Counties, California: U.S. Geological Survey Open-file map.
Brabb, E. E., and Pampeyan, E. H., 1972, Preliminary map of landslides in San Mateo County, Califomia: U.S. Geological Survey Miscellaneous Field Studies Map MF-344.

Brabb, E. E., and Dibblee, T. W., Jr., 1979, Preliminary geologic map of the Castle Rock Ridge quadrangle, Santa Cruz and Santa Clara Counties, Califomia: U.S. Geological Survey Open-File Report 79-659.

Brown, R. D., Jr., and Lee, W. H. K., 1971, Active faults and preliminary earthquake epicenters (1969-70) in the southern part of the San Francisco Bay region: U.S. Geological Survey Miscellaneous Field Studies Map MF-307.

Bufe, C. G., Lester, F. W., Meather, K. L., and Wesson, R. L., 1975, Catalog of earthquakes along the San Andreas fault system in central Califomia, April-June 1973: U.S. Geological Survey Open-File Report 75-125, $44 \mathrm{p}$.

California Division of Mines and Geology, 1965 Potassium-argon age dates for some California localities: California Division of Mines and Geology Mineral Information Service, v. 18 , no. 1, p. 16.

Chapman, R. H., and Bishop, C. C., compilers, 1968, Bouguer gravity map of California-San Francisco sheet: San Francisco, Calif., California Division of Mines and Geology, scale 1:250,000.

Clark, J. C., 1966, Tertiary stratigraphy of the FeltonSanta Cruz area, Santa Cruz Mountains, Califomia: Stanford University Ph.D. thesis.

1968, Correlation of the Santa Cruz Mountains

Tertiary-Implications for San Andreas history, in Conference on geologic problems of San Andreas fault system, Stanford, Calif., 1967, Proc.: Stanford University Publications, Geological Science, v. 11, p. 166-180.

1970, Geologic map of the Davenport area, Santa Cruz County, California: U.S. Geological Survey Open-file Report, scale 1:24,000.

Clark, J. C., and Rietman, J. D., 1973, Oligocene stratigraphy, tectonics and paleogeography southwest of the San Andreas fault, Santa Cruz Mountains and Gabilan Range, California Coast Ranges: U.S. Geological Survey Professional Paper 783, $18 \mathrm{p}$.

Cotton, W. R., 1972, Preliminary geologic map of the Franciscan rocks in the central part of the Diablo Range, Santa Clara and Alameda Counties, California: U.S. Geological Survey Miscellaneous Field Studies Map MF-343, scale 1:62,500.

Crawford, Ken, 1976, Reconnaissance geologic map of the Eylar Mountain quadrangle, Santa Clara and Alameda Counties, Califronia: U.S. Geological Survey Miscellaneous Field Studies Map MF-764.

Crittenden, M. D., Jr., 1951, Geology of the San Jose and Mount Hamilton quadrangles, California: California Division of Mines and Geology Bulletin 157.

Curtis, G. H., Evernden, J. F., and Lipson, J., 1958, Age determination of some granitic rocks in California by the potassium-argon method: California Division Mines and Geology Special Report 54, 16 p.

Dibblee, T. W., Jr., 1966, Geology of the Palo Alto quadrangle, Santa Clara and San Mateo Counties, California: Califomia Division of Mines and Geology Map 8, scale 1:62,500.

1972a, Preliminary geologic map of the Milpitas quadrangle, Alameda and Santa Clara Counties, Califomia: U.S. Geological Survey Open-File Report, scale 1:24,000. 
1972b, Preliminary geologic map of the San Jose East quadrangle, Santa Clara County, California: U.S. Geological Survey Open-File Report, scale $1: 24,000$.

1972c, Preliminary geologic map of the Lick Observatory quadrangle, Santa Clara County, California: U.S. Geological Survey Open-File Report, scale $1: 24,000$.

1973a, Preliminary geologic map of the Calaveras Reservoir quadrangle, Alameda and Santa Clara Counties, California: U.S. Geological Survey Open-File Report, scale 1:24,000.

$1973 \mathrm{~b}$, Preliminary geologic map of the Morgan Hill quadrangle, Santa Clara County, California: U.S. Geological Survey Open-File Report, scale 1:24,000. $1973 c$, Preliminary geologic map of the Mt. Sizer quadrangle, Santa Clara County, California: U.S. Geological Survey Open-File Report, scale 1:24,000: 1973d, Preliminary geologic map of the Mt. Madonna quadrangle, Santa Clara and Santa Cruz Counties, California: U.S. Geological Survey Open-File Report, 1:24,000. $1973 e$, Preliminary geologic map of the Gilroy quadrangle, Santa Clara County, California: U.S. Geological Survey Open-File Map, scale 1:24,000. 1973f, Preliminary geologic map of the Gilroy Hot Springs quadrangle; Santa Clara County, California: U.S. Geological Survey Open-File Report, scale $1: 24,000$.

1975a, Geologic map of the Hollister quadrangle, Califomia: U.S. Geological Survey Open-File Map 75-394.

1975b, Geologic map of the Quien Sabe quadrangle, California: U.S. Geological Survey Open-File Map 75-394, scale 1:62,500.

Dibblee, T. W., Jr., and Brabb, E. E., 1978, Preliminary geologic maps of the Chittenden, Los Gatos, and Watsonville East Quadrangles, California: U.S. Geological Survey Open-File Report 78-453.

Dibblee, 'T. W., Jr., Brabb, E. E., and Clark, J. C., 1978, Preliminary geologic map of the Laurel quadrangle, Santa Cruz and Santa Clara Counties, Califomia: U.S. Geological Survey Open-File Report 78-84.

Duprẽ, W. R., 1975, Maps showing geology and liquefaction potential of Quaternary deposits in Santa Cruz County, California: U.S. Geological Survey Miscellaneous Field Studies Map MF-648.

Evernden, J. F., and Savage, D. E., Curtis, G. H., and James, G. T., 1964, Potassium-argon dates and the Cenozoic mammalian chronology of North America: American Journal of Science, v. 262, p. 145-198.

Greene, J. G., Lee, W. H. K., McCulloch, D. S., and Brabb, E. E., 1973, Faults and earthquakes in the Monterey Bay region, California: U.S. Geological Survey Miscellaneous Field Studies Map MF-518, 4 sheets, scale 1:250,000.

Griscom, Andrew, 1966, Magnetic data and regional structure in northern Califomia, in Bailey, E. H., ed., Geology of northern California: California Division of Mines and Geology Bulletin 190, p. 407-417.

Hall, C. A., Jr., 1958, Geology and paleontology of the Pleasanton area, Alameda and Contra Costa Counties, Califomia: Califomia University Publications in Geological Sciences, v. 34, no. 1, p. 1-90.

Hanna, W. F., Brown, R. D., Jr., Ross, D. C., and Griscom, Andrew, 1972, Aeromagnetic reconnaissance and generalized geologic map of the San Andreas fault be- tween San Francisco and San Bernardino, California: U.S. Geological Survey Geophysical Investigation Map GP-815, scale 1:250,000

Herd, D. G., 1977a, Map of Quaternary faulting along the Hayward and Calaveras fault zones, Niles and Milpitas $7.5^{\prime}$ quadrangles, California: U.S. Geological Survey Open-File Report 77-645.

1977b, Geologic map of the Las Positas, Greenville, and Verona faults, eastern Alameda County, California: U.S. Geological Survey Open-File Report 77-689.

1978a, Map of Quaternary faulting along the northern Hayward fault zone, Mare Island, Richmond, Briones Valley, Oakland West, Oakland East, San Leandro, Hayward, and Newark 7.5' quadrangles, California: U.S. Geological Survey Open-File Report 78-308

1978b, Map of Quaternary faulting along the northern Calaveras fault zone, Los Trampas Ridge, Diablo, Dublin, Niles, and La Costa Valley 7.5' quadrangles, California: U.S. Geological Survey Open-File Report 78-307.

Huey, A. S., 1948, Geology of the Tesla quadrangle, California: California Division of Mines Bulletin 140, p. 37.

Lanphere, M. A., 1971, Age of Mesozoic oceanic crust in the California Coast Ranges: Geological Society of America Bulletin, v. 82, p. 3209-3212.

Lee, W. H. K., Eaton, M. S., and Brabb, E. E., 1971, The earthquake sequence near Danville, California, 1970: Seismological Society of America Bulletin, v. 61, no. 6, p. 1771-1794

Lee, W. H. K., Roller, J. C., Bauer, P. G., and Johnson, J. D., 1972, Catalog of earthquakes along the San Andreas fault system in central Califomia for the year 1969: U.S. Geological Survey Open-File Report, 48 p.

Lee, W. H. K., Roller, J. C., Meagher, K. L., and Bennett, R. E., 1972, Catalog of earthquakes along the. San Andreas fault system in central California for the year 1970: U.S. Geological Survey Open-File Report, 73 p.

Lee, W. H. K., Meagher, K. L., Bennett, R. E., and Matamoros, E. E., 1972, Catalog of earthquakes along the San Andreas fault system in central California for the year 1971: U.S. Geological Survey Open-File Report, $67 \mathrm{p}$.

Leith, C. J., 1949, Geology of the Quien Sabe quadrangle, California: Califomia Division of Mines and Geology Bulletin 147, scale 1:62,500.

Leo, G. W., 1967, The plutonic and metamorphic rocks of the Ben Lomond Mountain area, Santa Cruz County, California, in Short contributions to Califomia geology: California Division of Mines and Geology Special Report 91, p. 27-43.

Lester, F. W., Kirkman, S. L., and Meagher, K. L., 1976, Catalogue of earthquakes along the San Andreas fault system in central California, October-September, 1973: U.S. Geological Survey Open-File Report 76-732.

Lester, F. W., Meagher, K. L., and Wesson, R. L., 1976, Catalogue of earthquakes along the San Andreas fault system in central California, July-September 1973: U.S. Geological Survey Open-File Report 76-169.

McLaughlin, R. J., Simoni, T. R., Osbun, E. D., and Bauer, P. G., 1971, Geologic map of the Loma Prieta-Mount Madonna area, Santa Clara and Santa Cruz Counties, California: U.S. Geological Survey Open-File Report, scale $1: 24,000$. 
Maddock, M. E., 1964, Geology of the Mt. Boardman quadrangle, Santa Clara and Stanislaus Counties, Califomia: California Division of Mines and Geology Map sheet 3, scale 1:62,500.

Naeser, C. W., and Ross, D. C., 1976, Fission-track ages of sphene and apatite of granitic rocks of Salinian block, Coast Ranges, California: Journal of Research, U.S. Geological Survey, v. 4, no. 4, p. 415-420.

Nakata, J. K., 1977, Distribution and petrology of the Anderson-Coyote reservoir volcanic rocks: San Jose State University, unpublished M.S. thesis, 105 p.

Prowell, D. C., 1974, Geology of selected Tertiary volcanics in the central Coast Range Mountains of California and their bearing on the Calaveras and Hayward fault problems: Santa Cruz, Califomia University Ph.D. thesis, $182 \mathrm{p}$.

Radbruch, D. H., 1957, Areal and engineering geology of the Oakland West quadrangle, Califomia: U.S. Geological Survey Miscellaneous Investigations Series Map I-239, scale 1:24,000.

1969, Areal and engineering geology of the Oakland East quadrangle, Califomia: U.S. Geological Survey Geological Quadrangle Map GQ-769, scale $1: 24,000$.

Radbruch, D. H., and Case, J. E., 1967, Preliminary geologic map and engineering geologic information,. Oakland and vicinity, Califomia: U.S. Geological Survey Open-File Report, scale 1:24,000.

Robinson, G. D., 1956, Geologic map of Hayward Califomia: U.S. Geological Survey Geologic Quadrangle Map GQ-88, scale 1:24,000.

Rogers, T. H., 1966, compiler, Geologic map of California, San Jose sheet: California Division of Mines and Geology, scale 1:250,000.

Rogers, T. H., and Williams, J. W., 1974, Potential seismic hazards in Santa Clara County, Califomia: California Division of Mines and Geology Special Report 1.07, 39 p., scale 1:62,500.

Rose, R. L., 1978, Age of the Alum Rock rhyolite (abs.): Geological Society of America Abstracts with Programs, v. 10 , no. 3 , p. 144.

Ross, D. C., 1970, Quartz gabbro and anorthosite gabbro, markers of offset along the San Andreas fault in the Califomia Coast Ranges: Geological Society of America Bulletin, v. 81, no. 12 , p. $3647-3661$.

Saad, A. H., 1969, Magnetic properties of ultramafic rocks from Red Mountain, California: Geophysics, v. 34, no. 6, p. 974-987.

1969b, Paleomagnetism of Franciscan ultramafic rocks from Red Mountain, Califomia: Journal of Geophysical Research, v. 74, no. 27, p. 6567-6578.

Sarna-Wojcicki, A. M., Pampeyan, E. H., and Hall, N. T., 1975, Map showing recently active breaks along the San Andreas fault between the central Santa Cruz Mountains and the northern Gabilan Range, California: U.S. Geological Survey Miscellaneous Field Studies Map MF-650, scale 1:24,000.

Soliman, S. M., 1965, Geology of the east half of the Mount Hamilton quadrangle, California: Califormia Division of Mines and Geology Bulletin 185, $32 \mathrm{p}$.

Taliaferro, N. L., 1949, Geologic map of the Hollister quadrangle, California: California Division of Mines and Geology Bulletin 143, scale 1:62,500

Tatlock, D. B., and Berkland, J. O., 1961, Leona "Soda" Rhyolite, Alameda County, California-Primary or metasomatic?: Geological Society of America Abstracts, 1961, Cordilleran Section, San Diego, p. 58-59.

Tumer, D. L., 1970, Potassium-argon dating of Pacific Coast Miocene foraminiferal stages, in Radiometric dating and paleontologic zonation: Geological Society of America Special Paper 124, p. 91-129.

U.S. Geological Survey, 1971, Aeromagnetic map of the southern part of the San Francisco Bay region, California: U.S. Geological Survey Open-File Report.

1974, Aeromagnetic maps of the San Francisco Bay region: U.S. Geological Survey Open-File Report.

Wagner, J. R., 1978, Late Cenozoic history east of San Francisco Bay: Berkeley, California University Ph.D. thesis.

Wallace, R. E., 1974, Goals, strategy, and tasks of the earthquake hazard reduction program: U.S. Geological Survey Circular 701, 26 p.

Wesson, R. L., Bennett, R. E., and Meagher, K. L., 1972 , Catalog of earthquakes along the San Andreas fault system in central California, January-March, 1972: U.S. Geological Survey Open-File Report, 60 p.

Wesson, R. L., Meagher, K. L., and Lester, F. W., 1973, Catalog of earthquakes along the San Andreas fault system in central California, July-September, 1972 : U.S. Geological Survey Open-File Report, 49 p.

Wesson, R. L., Lester, F. W., and Meagher, K. L., 1974, Catalog. of earthquakes along the San Andreas fault system in central California January-March 1973: U.S. Geological Survey Open-File Report 74-186, 47 p.

Wesson, R. L., Helley, E. J., Lajoie, K. R., and Wentworth, C. M., Jr., 1975, Faults and future earthquakes, in Studies for seismic zonation of the San Francisco Bay region: U.S. Geological Survey Professional Paper 941-A, p. A5-A30. 